\title{
Technological Pedagogical Content Knowledge (TPACK) for Pedagogical Improvement: Editorial for Special Issue on TPACK
}

\author{
Joyce Hwee Ling Koh ${ }^{1}$ Ching Sing Chai ${ }^{1} \cdot$ Min-Hsien Lee ${ }^{2}$
}

Published online: 28 May 2015

(C) De La Salle University 2015

Mishra and Koehler's (2006) framework for technological pedagogical content knowledge (TPACK) is one of the most well-received and widely researched theoretical frameworks for technology integration in the classrooms. Chai et al. (2013) recent review found that more than 70 articles about TPACK have been published between 2003 and 2011 within the Scopus database. A website dedicated to TPACK research (http://tpack.org/) has accumulated more than 450 articles. The SSCI-listed journals have also published 134 articles on TPACK as of May 2015. As an analytical and creative framework, TPACK research can potentially generate deeper knowledge construction about ICT integration among researchers and educators. It could be refined, expanded, and improved upon to account for more variables that shape, empower, or constrain the development of ICT use in education (Chai et al. 2013; Voogt et al. 2013).

Building upon Shulman's (1986) model for pedagogical content knowledge, Mishra and Koehler (2006) added the dimension of technological knowledge and demonstrated how various kinds of teacher knowledge can be derived from the integration of technological, pedagogical, and content knowledge. These integrated forms of knowledge are pedagogical content knowledge (PCK), technological content knowledge (TCK), technological pedagogical knowledge (TPK), and technological pedagogical content

Joyce Hwee Ling Koh

joyce.koh@nie.edu.sg

1 National Institute of Education, Nanyang Technological University, Singapore, Singapore

2 Center for Teacher Education \& Institute of Education, National Sun Yat-sen University, Kaohsiung, Taiwan knowledge (TPACK). Together with technological knowledge (TK), pedagogical knowledge (PK), and content knowledge (CK), these seven kinds of knowledge make up the TPACK framework.

While this framework provides specifications for the kinds of teacher knowledge involved during technology integration, how teachers, educators, and researchers can create more technological pedagogical content knowledge need to be further unpacked. Tee and Lee (2011) have aptly positioned generating TPACK as a knowledge creation endeavor and Kramarski and Michalsky (2010) have found it necessary to support pre-service teachers' metacognitive self-regulation as they create TPACK through design. The creation of knowledge is a complex matter and coupled with the situated nature of TPACK (Mishra and Koehler 2006); further theorizing of the epistemic nature and processes involved in creating TPACK are needed. Specifically, the TPACK framework specifies what teachers need to integrate technology but not how the process can be improved (Cox and Graham 2009).

On the other hand, there is much emphasis on the use of technology to support pedagogical improvements, especially the kinds of pedagogies that support students to foster twenty-first century competencies (ISTE 2007; P21, 2007). Voogt and Roblin (2012) have identified ICT-based learning as a common element across all twenty-first century learning frameworks they have reviewed. ICT could be used as a cognitive tool, metacognitive tool, and epistemic tool to support critical thinking, creative and inventive thinking and authentic problem solving, which are also common elements of twenty-first century learning. Yet, there is still a lack of understanding about how the seven TPACK constructs are being applied by teachers as they formulate technology-integrated lessons to promote twenty-first century learning 
(Cox and Graham 2009; Graham 2011). Much work is therefore needed to expand and refine the theoretical constructs of TPACK as well as to associate it with other theoretical framework and factors that influence ICT integration.

Given the current gaps in TPACK research, this special issue seeks to explore how teachers and educators develop TPACK and apply it as a theoretical framework to guide their planning of pedagogical improvements during lesson planning and implementation. The first article by $\mathrm{Hsu}$, Liang, and Su explores how TPACK constructs can be used to guide the content sequencing decisions of an in-service course that taught Taiwanese preschool teachers to design and incorporate game-based pedagogies. The study found that the group of teachers who were taught game knowledge first (TK) perceived higher levels of technological pedagogical content knowledge-games (TPACK-G) than those who were taught the PK associated with game-based learning first. Qualitative analysis of the teachers' lesson plans also found that those designed by the first group of teachers had more diverse game strategies and better integration of technology, pedagogy, and content. These results suggest that TK may be a critical starting point for building preschool teachers' TPACK-G.

The second paper by $\mathrm{Wu}$ and Wang demonstrates how TPACK surveys can be used together with interviews and observations of teaching performance to support the diagnosis of the professional development needs of Taiwanese elementary school teachers of English as a foreign language (EFL). To do so, the authors had to modify survey items from Koh et al. (2010), and Sahin (2011) for the English language domain as well as draw upon Egbert and Hanson-Smith's (1999) pedagogical framework for computer-assisted language learning (CALL) in the analysis of their interview and observation results. This multi-pronged approach for TPACK evaluation found that even though teachers' self-reported TPACK survey ratings were generally above average, the interviews and observations revealed that these EFL teachers tend to use technology for content delivery and to a lesser extent for stimulating participant interaction. This study exemplifies how comprehensive TPACK evaluation through the use of both qualitative and quantitative data can be used to support the diagnosis of teachers' professional development needs.

It is recognized that teachers' pedagogical practices for technology integration are influenced by their beliefs and conceptions of teaching, examples of what Ertmer (1999) defined as second-order barriers. The third paper by Liang examines if preschool teachers' perceptions of authority and control in the classroom has any influence on their perceptions of TPACK. Their cluster analysis of 303 Taiwanese in-service preschool teachers with the preschool teacher authority scale (PTAS) derived four types of classroom authority perceptions: Teachers with Low
Engagement in classroom authority, Surface Constructivist teachers who did not support teacher-centered activities, those with preference for Teacher Dominance, as well as High Commitment teachers who had the high agreement for student autonomy, participation from children as well as the need for student dependence on teacher for correct solutions. It was found that teachers in the High Commitment cluster had the strongest perceptions of TCK, TPK, and TPACK. These findings suggest that teachers who are comfortable to toggle between student autonomy and teacher control may be more confident with ICT integration.

Some studies have attempted to specify TPACK for online instruction (e.g., Archambault and Crippen 2009, Lee and Tsai 2010). The fourth paper by Lee, Mohamed, and Altamimi presents an example of how the TPACK framework can be used in the design and development of an online e-learning tutorial system for Malaysian special needs educators of the Malay braille code. A multidisciplinary team with braille knowledge, educational technology knowledge, as well as systems development knowledge contributed to the different aspects of content, pedagogy, and technology that framed the system. TPACK was externalized as an e-learning system that incorporates pedagogical agents, braille simulation, flash models, worked examples, practice exercises with corrective feedback, as well as automated formative and summative tests. When evaluated with 77 pre-service special needs educators, positive results were obtained in terms of learner satisfaction and confidence of system use. These results demonstrate how TPACK can be used for effective design of educational software and technology-based learning environments.

A notable gap in TPACK research is the need for TPACK that is contextualized to specific content and pedagogical applications. The fifth paper by Evans, Nino, Deater-Deckard, and Chang examines the instructional decisions undertaken by teachers from two school districts in Virginia, USA as they attempted to implement [The Math App], an iPadspecific learning game designed for the learning of fractions. This study exemplifies how TPACK can be used as a theoretical lens to consider the various instructional decisions that are related to technology, pedagogy, and content. The study shows that to facilitate students' adoption of the game, the teachers need to enhance their TK, to become gamers themselves. Teachers also need to create linkages between PCK and TK by supplementing game-based learning with non-technology strategies such as discussions and journals. Through incorporating the game, teachers reconsider their $\mathrm{CK}$ associated with it. These findings provide insights about the different considerations for successful instructional alignment.

The sixth paper by Finger et al. describes the use of TPACK as a framework for nation-wide planning of 
teacher ICT development in the teaching teachers for the future project (TTF) in Australia. This $\$ 8$ million project was funded by the Australian Government specifically for ICT competency development of Australian pre-service teachers and it involved 39 Australian Higher Education providers of initial teacher training. The TTF TPACK survey assessed teachers' change in confidence with technological pedagogical knowledge (TPK), technological content knowledge (TCK), and TPACK, as well as teachers' perceived confidence with ICT and perceived usefulness of ICT before and after the TTF interventions. Correspondingly, Most Significant Change (MSC) stories were used to document important domains and patterns of change throughout these interventions. This paper provides a valuable example of TPACK's potential use for the planning, development, and evaluation of large-scale teacher development programs.

The seventh paper by Xiong and Lim discusses two examples where pre-service teachers' TPACK is shaped by curriculum planning in teacher education programs, and is in turn shaped by the decisions of the programs' curriculum leaders. Their study shows that the values, beliefs, and experience of curriculum leaders toward ICT integration, their perceptions of contextual challenges, feedback from pre-service teachers, as well as the effectiveness of collaboration among curriculum leaders are some factors that influence the program processes adopted. These processes influence the learning experiences of teachers and subsequently their confidence for ICT integration which can be observed through their TPACK perceptions. This paper suggests that it is needful to consider the interactions of TPACK and curriculum leadership more deeply.

The final theoretical piece by Koh, Chai, Wong, and Hong discusses the difficulties faced by teachers when designing ICT lessons to support twenty-first century learning and argues for the need to consider both TPACK and design thinking when doing so. The authors explicate a conceptual framework by drawing upon design thinking literature which views teachers' design process as being non-sequential and episodic; highly dependent upon how teachers play with ideas, develop design frames, and engage in reflection-in-action as they develop and implement their lessons. The various constructs of TPACK are being conceptualized as epistemic resources that teachers draw upon to support their design thinking. The framework presents an example of how various forms of teachers' TPACK can be evoked through guide questions developed to stimulate thinking about critical twenty-first century learning issues throughout the design process.

The papers in this special issue have showcased different ways of using TPACK for instructional planning, curriculum leadership, e-learning, and teacher assessment; notably including teachers in the fields of early childhood and special needs, which have not often been studied. Several areas in the field of TPACK can still be further developed. Firstly, TPACK has contextualized knowledge for ICT used with specific content and pedagogies. Unique kinds of TPACK specifications still need to be developed as languages of pedagogical improvement for different contexts; which are examples of what Harris et al. (2009) defined as TPACK Activity Types. Harris and Hofer (2011) have begun some work on such kinds of activity types in different subject areas. More of such studies are still needed. Secondly, Chai et al. (2013) suggested that the TPACK framework can also be extended to the assessment of the design of online activities. Thirdly, how teachers use their existing knowledge as epistemic resource to create TPACK under the influence of their epistemic and pedagogic beliefs needs further unpacking. Chai et al. (2011) have alluded that the nature of TPACK as a form of knowledge is not that of "verified true beliefs" but "usable design knowledge". The process of generating TPACK could be partly through the dynamic activation of epistemic resources, which inevitably include the seven kinds of TPACK knowledge that the teachers may possess. Teachers' acquired ways of framing design problems and the situational and discursive synthesis of the epistemic resources to solve the instructional problems at hand could also contribute to the creation of TPACK. Teachers' decisions could also be influenced by the multiple demands that they face as part of the context of their work, and their personal intentions with using technology. Further analysis of how contextual factors influence teacher's TPACK development is thus necessary (Porras-Hernasndez and Salinas-Amescua 2013). Furthermore, how TPACK is generated from the perspective of teachers' mental models (see for e.g., Krauskopf et al. 2012) needs further theorization and empirical illustration. This constitutes an area of study that can be further explored. As teachers change their pedagogical practices with technology integration, such are examples of TPACK that are being enacted in the classroom. Such kinds of change influences students' conception of learning with technology (Hammond and Manfra 2009; Khan 2011). The fourth area for future study therefore relates to the effects of teachers' TPACK application on students either in terms of learning outcomes or their conceptions of learning with technology. A final gap observed is the lack of critical perspectives about the TPACK framework (Hewitt 2008) as most papers have accepted the TPACK framework as it is even though a theoretical analysis of the TPACK constructs find the need for much more precision in its theoretical definitions (Cox and Graham 2009). Therefore, studies that consider alternative interpretations of the TPACK frameworks can further enhance the critical discourse and theoretical development of the framework. These are several potential 
areas that can contribute to the enhancement of the TPACK framework's usefulness for supporting teachers' pedagogical improvement.

\section{References}

Archambault, L. M., \& Crippen, K. (2009). Examining TPACK among K-12 online distance educators in the United States Vol. 9. Contemporary issues in technology and teacher education. Retrieved from http://www.citejournal.org/vol9/iss1/general/arti cle2.cfm.

Chai, C. S., Koh, J. H. L., \& Tsai, C. C. (2013). A review of technological pedagogical content knowledge. Education Technology and Society, 16(2), 31-51.

Chai, C., Koh, J., Tsai, C., \& Tan, L. (2011). Modeling primary school pre-service teachers' Technological Pedagogical Content Knowledge (TPACK) for meaningful learning with information and communication technology (ICT). Computers \& Education, 57(1), 1184-1193.

Cox, S., \& Graham, C. R. (2009). Diagramming TPACK in practice: Using and elaborated model of the TPACK framework to analyse and depict teacher knowledge. TechTrends, 53(5), 60-69.

Egbert, J., \& Hanson-Smith, E. (Eds.). (1999). CALL environments: Research, practice, and critical issues. Alexandria, VA: Teachers of English to Speakers of Other Languages.

Ertmer, P. A. (1999). Addressing first-and second-order barriers to change: Strategies for technology integration. Educational Technology Research and Development, 47(4), 47-61.

Graham, C. R. (2011). Theoretical considerations for understanding technological pedagogical content knowledge (TPACK). Computers \& Education, 57(3), 1953-1960.

Hammond, T. C., \& Manfra, M. (2009). Giving, prompting, making: Aligning technology and pedagogy within TPACK for social studies instruction. Contemporary Issues in Technology and Teacher Education (CITE Journal), 9(2), 160-185.

Harris, J. B., \& Hofer, M. J. (2011). Technological pedagogical content knowledge (TPACK) in action: A descriptive study of secondary teachers' curriculum-based, technology-related instructional planning. Journal of Research on Technology in Education, 43(3), 211.

Harris, J., Mishra, P., \& Koehler, M. (2009). Teachers' technological pedagogical content knowledge and learning activity types: Curriculum-based technology integration reframed. Journal of Research on Technology in Education, 41(4), 393-416.

Hewitt, J. (2008). Reviewing the handbook of technological pedagogical content knowledge (TPCK) for educators. Canadian Journal of Science, Mathematics, and Technology Education, $8(4), 355-360$.
ISTE. (2007). The national educational technology standards and performance indicators for students. Eugene, OR: International Society for Technology. in Education.

Khan, S. (2011). New pedagogies on teaching science with computer simulations. Journal of Science Education \& Technology, 20(3), 215-232. doi:10.1007/s10956-010-9247-2.

Koh, J. H. L., Chai, C. S., \& Tsai, C. C. (2010). Examining the technology pedagogical content knowledge of Singapore preservice teachers with a large-scale survey. Journal of Computer Assisted learning, 26(6), 563-573.

Kramarski, B., \& Michalsky, T. (2010). Preparing preservice teachers for self-regulated learning in the context of technological pedagogical content knowledge. Learning and Instruction, 20(5), 434-447.

Krauskopf, K., Zahn, C., \& Hesse, F. W. (2012). Leveraging the affordances of Youtube: The role of pedagogical knowledge and mental models of technology functions for lesson planning with technology. Computers \& Education, 58, 1194-1206.

Lee, M.-H., \& Tsai, C.-C. (2010). Exploring teachers' perceived self efficacy and technological pedagogical content knowledge with respect to educational use of the World Wide Web. Instructional Science, 38, 1-21.

Mishra, P., \& Koehler, M. J. (2006). Technological pedagogical content knowledge: A framework for teacher knowledge. Teachers College Record, 108(6), 1017-1054.

Porras-Hernasndez, L. H., \& Salinas-Amescua, B. (2013). Strengthening TPACK: A broader notion of context and the use of teacher's narratives to reveal knowledge construction. Journal of Educational Computing Research, 48(2), 223-244.

Sahin, I. (2011). Development of survey of technological pedagogical and content knowledge (TPACK). Turkish Online Journal of Educational Technology, 10(1). Retrieved from http://tojet.net/ articles/10110.pdf

Shulman, L. S. (1986). Those who understand: Knowledge growth in teaching. Educational Researcher, 15(2), 4-14. doi:10.3102/00 13189x015002004.

Tee, M., \& Lee, S. (2011). From socialisation to internalisation: Cultivating technological pedagogical content knowledge through problem-based learning. Australasian Journal of Educational Technology, 27(1), 89-104.

Voogt, J., Fisser, P., Roblin, N. P., Tondeur, J., \& van Braak, J. (2013). Technological pedagogical content knowledge-A review of the literature. Journal of Computer Assisted Learning, 29(2), 109-121.

Voogt, J., \& Roblin, N. P. (2012). A comparative analysis of international frameworks for 21 st century competences: Implications for national curriculum policies. Journal of Curriculum Studies, 44(3), 299-321. 